\title{
Gendered Paths to Asset Accumulation? Markets, Savings, and Credit in Developing Countries
}

Cheryl Doss, Carmen Diana Deere, Abena D. Oduro, Hema Swaminatham, Zachary Catanzarite, and Suchitra J.Y.

\begin{abstract}
:
An extensive literature focuses on how the inheritance of property is biased against women in many developing countries, yet relatively little attention has been given to other means of acquiring physical assets, such as the market. Using individual-level data from Ecuador, Ghana, and Karnataka, India, we analyze the modes of acquisition and financing of housing, agricultural land, other real estate, and businesses. We find that women acquire fewer of their assets through the market than men. When they participate in asset markets, both men and women are more likely to use their own savings than to use credit. We also analyze current loans for asset acquisition and find different country patterns, but that women tend to be somewhat disadvantaged in securing formal bank loans. Our findings suggest that financial inclusion to promote the accumulation of assets should focus on both savings and credit with priority to the former.
\end{abstract}

Keywords:

Asset markets, inheritance, Ecuador, Ghana, India

JEL codes: E21; J16; O16; O57

Acknowledgements: The authors are grateful to Caren Grown, a co-Principal Investigator of the Gender Asset Gap project, who took the lead in our original analysis of access to credit. The Vanguard Foundation and UN Women funded this research effort. 


\section{Gendered Paths to Asset Accumulation? Markets, Savings and Credit in Developing Countries}

\section{Introduction}

A consensus is emerging among academics and policy makers that women's empowerment is associated with their ownership of property. Increasing poor women's property ownership may also provide them and their families a pathway out of poverty. The evidence suggests that women are less likely than men to own any form of immovable property. As development efforts target increasing women's property ownership, it is important to step back and examine how women accumulate property and whether the modes of acquisition differ for women and men. This would assist in understanding the constraints that women face in acquiring assets and developing ways to bridge the gender asset gap.

Individuals acquire assets through inheritance, state and/or community transfers of property, and markets. Much of the focus on women's asset acquisition in developing countries, particularly of land, has been on the gendered patterns of inheritance. Some attention has also been given to gender biases in state programs of land or housing distribution or in the privatization of community lands. Much less attention has been given to men and women's participation in asset markets, and the extent to which such participation is financed through savings and/or credit. As asset markets grow in importance, it is critical to understand their gender dimensions and, particularly, whether there are differences in how men and women finance their asset acquisitions.

Using detailed asset ownership data for individuals, we analyze how women and men acquire their immovable property ${ }^{1}$ and businesses in Ecuador, Ghana and Karnataka, India. These assets constitute the bulk of household physical or non-financial gross wealth: 90 percent in Ecuador, 82 percent in Ghana and 93 percent in Karnataka.

The three countries represent very different patterns of urbanization and market development and have different legal norms, all of which have crosscutting impacts on the potential for asset accumulation by both women and men. Ecuador, a high middle-income country, is more urban than either Ghana or India, both low middle-income countries. ${ }^{2}$ In Ecuador, agricultural land is relatively less important in the aggregate wealth portfolio than in the other two countries, and the real estate market in both rural and urban areas is fairly well developed. In contrast, in Ghana, much of the land and housing in rural areas continues to be under customary tenure, with kinship and community playing an important role in access to property. In India, agricultural land is the most important asset of the majority of the population, which is still rural. Land is more often transferred inter-generationally than by any other means, and land markets are not well developed. Overall, inheritance is a much more important means of acquiring land and other immovable property in Ghana and India than in Ecuador.

\footnotetext{
${ }^{1}$ Immovable property includes the principal residence, agricultural land and other real estate (the latter including non-agricultural lots, dwellings other than the principal residence, and buildings that are not part of a business).

2 http://siteresources.worldbank.org/EXTNWDR2013/Resources/8258024-1352909193861/89369351356011448215/8986901-1380046989056/10--Appendixes.pdf. Accessed October 1, 2015.
} 
The three countries also differ with respect to their marital regimes, with important implications for women's property ownership. Ghana and India are characterized by the separation of property marital regime whereby property acquired within marriage is considered the exclusive property of the individual who acquired it or in whose name it is legally registered. Ecuador, by contrast, has the more gender-inclusive partial community property regime whereby any property bought during marriage is the joint property of both spouses. Not surprisingly, the gender asset gap among couples is minimal in Ecuador compared to the other two countries where it looms large (Carmen Diana Deere, Abena D. Oduro, Hema Swaminathan, and Cheryl Doss, 2013).

Irrespective of the degree of development of asset markets, there are differences in the patterns of modes of acquisition of property by gender. In each of the three countries, women acquire fewer of their assets through the market than men. For both men and women who acquire immovable property and businesses through the market, the use of savings is the most common way of financing the acquisition. Relatively few of these assets have been purchased using credit.

In addition to this retrospective analysis of how assets have been acquired, we consider current loans that have been utilized for asset acquisition in Ecuador and Ghana. Loans for this purpose are more readily available in Ecuador than in Ghana, but in the former there is a large gender gap in favor of men. Further, while in Ecuador the great majority of the loans for asset acquisition are from formal sources, in Ghana, informal sources predominate. In both countries, private bank credit favors men.

As markets for immovable property become increasingly important in developing countries and as the opportunities for opening and expanding businesses increase, it is critical that women be able to acquire assets on the same terms as men. While strengthening women's inheritance rights and ensuring that these are honored in practice will always be important, it is necessary to also ensure that women have access to formal financial institutions, including savings accounts, to acquire assets through the market.

\section{Patterns of Asset Acquisition}

Assets may be acquired through inheritance, the market, or state or community transfers, but the two most common means of asset acquisition are inheritance and purchase. A long-standing debate in the literature on wealth accumulation in developed countries regards the extent to which wealth is accumulated primarily through inheritance rather than self-acquired - via savings and the market - and the impact on wealth inequality. This debate concludes that inherited wealth is more concentrated than the distribution of wealth as a whole (James Davies and Anthony Shorrocks 2000). Estimates of the share of households who have ever received an inheritance vary widely: from only 4.4 percent in the United Kingdom and 12.0 percent in the United States, to over 40 percent in Sweden, Belgium and Switzerland (Moshe Semyonov and Noah Lewin-Epstein 2013: 1138).

Similar analyses have yet to be done for developing countries, so we do not know much regarding the relative importance of these sources of wealth and how they might change in the process of development. The variation in the incidence of inheritance in developed countries, however, suggests that this process is certainly heterogeneous. 
In addition, very little is known about how the broad patterns of asset acquisition differ for men and women, although there has been substantive research on particular aspects. Women often face discrimination in inheritance, with sons favored over daughters in many regions of the world; but women may also face constraints in acquiring assets through markets. The extent to which these constraints affect the overall patterns of asset acquisition for men and women have not been studied systematically (Carmen Diana Deere and Cheryl Doss 2006).

An extensive literature focuses on the discrimination against women in inheritance law and practice regarding immovable property, specifically agricultural land and housing. ${ }^{3}$ This issue was recognized in the international arena through the 1979 UN Convention on the Elimination of All Forms of Discrimination against Women (CEDAW), and since then, many countries have passed legislation strengthening women's inheritance rights, especially under intestate succession. These initiatives, however, have had limited success in changing actual inheritance practices.

For example, the Hindu Succession Act (1956) in India was amended in 2005 to correct gender inequalities in inheritance by sons and daughters. This law could potentially benefit many Indian women, but has faced implementation challenges, such as poor understanding of the legislation, communities not recognizing women as landowners, and women themselves being hesitant to assert their rights (Ashok Sircar and Sohini Pal 2014). In Ghana, the Wills Act of 1971 did not contain explicit provisions for inheritance by sons and daughters. The intent of the Intestate Succession Act of 1985 was to protect the interests of surviving spouses and while it provides for children to inherit a portion of the estate of the deceased parent, there is no provision for sons and daughters to inherit equally. It too has faced implementation challenges (Jeanmarie Fenrich and Tracy Higgins 2001).

The increasing formalization of property rights and the growing commoditization of land and other property have brought new challenges for strengthening women's property rights. State titling programs have often resulted in land and housing being titled only in the name of the male head of household with women losing many of their claims (Susana Lastarria-Cornhiel 1997). However, a growing number of countries are now recognizing the importance of joint titling of immovable property in the names of both spouses in state programs (Deere and León 2001; Namita Datta 2006; Daniel Ayelew Ali, Klaus Deininger and Markus Goldstein 2014). The formalization of property rights is often designed explicitly to allow markets to play a greater role in allocating immovable property, particularly over time.

It cannot be assumed, however, that asset markets will be gender neutral, since participation in these depend on the purchasing power of individuals. If women have access to fewer financial resources than men, whether through savings or access to credit, they will be less likely to participate in asset markets and acquire assets in their own name. The ability to save is related to labor force participation and earnings. While women's labor force participation has been increasing in some world regions, most notably Latin America and the Caribbean, between 1990 and 2013 it fell in Central and Eastern Europe and Central Asia, and South Asia (UN Women 2015: Fig. 2.1). Moreover, in countries such as India, women's labor force participation is

\footnotetext{
${ }^{3}$ For a summary on South Asia, see Bina Agarwal (1995); on Latin America, Carmen Diana Deere and Magdalena León (2001); and on Africa, Elizabeth Cooper and Kate Bird (2012).
} 
concentrated in non-remunerated family labor, where they do not earn income directly. When they do earn income directly, women's wages are systematically lower (Elson 1999). Further, they do not always control the income they earn. ${ }^{4}$

Women's ability to purchase assets may also be limited by social norms. Susana LastarriaCornheil, Julia Behrman, Ruth Meinzen-Dick, and Agnes Quisumbing (2014) note that women have less access to land sales and rental markets not only because of financial constraints, but also because husbands may be reluctant for their wives to purchase land on their own. A woman who seeks to purchase property on her own may be perceived as a bad wife or one who is planning to leave her husband. Sellers of agricultural land may discriminate against women if women are not socially recognized as farmers. This was the case in northern Peru in the 1950s and 1960s, where some landowners would not sell land parcels to women or charged them higher prices (Carmen Diana Deere 1991).

Comparing the modes of acquisition of land among landowners from surveys in four Latin American countries, Deere and León (2001) find that although men are much more likely than women to have inherited land, the most frequent way that women landowners acquired their land was through inheritance. A much smaller share of women landowners than men landowners purchased their land, implicitly suggesting that women face greater challenges in land markets.

In much of Africa, women do not traditionally inherit land. They may acquire use rights to land through their husbands or fathers, but not ownership rights. Thus, the market may provide an important option for women to acquire land. In Uganda, a country with relatively well-developed land markets, an analysis in three regions of the country finds that women are more likely to purchase land than inherit it; 30 percent of women purchased land while 23 percent acquired it through inheritance or gifts. A gender gap prevails nevertheless given that 43 percent of male respondents had purchased land, and 41percent had inherited it (Cheryl Doss, Mai Truong, Goretti Nabanoga, and Justine Namaalwa 2012). ${ }^{5}$ Thus, even where land markets are active, women may face more constraints than men in participating in this market.

Regarding housing, Greta Friedemann-Sánchez (2006), in a study of floriculture workers in Colombia, found few gender differences in inheritance: male and female workers were similarly likely to have inherited a housing lot or dwelling. Among those who had purchased these assets, however, men were significantly more likely than women to have used their own savings. Women used a larger number of financial sources, relied more upon loans, and worked more years to acquire their property. Friedemann-Sánchez attributes these differences to cultural norms whereby women have greater family obligations than do men, and therefore save less. The main source of credit for these workers was an employee credit fund, with equal access for men and women.

The literature on business acquisition focuses more on use of credit, rather than comparing the roles of inheritance and markets, perhaps because the majority of small businesses in developing

\footnotetext{
${ }^{4}$ A study of 44 developing countries found that in thirteen, 10 percent or more of the women sampled reported that they were not involved in the decision on how to spend the income that they generated (World Bank 2012: Fig. 2.9). ${ }^{5}$ A survey only in Central Uganda reports slightly different results; while 40 percent of women had acquired land through inheritance, 43 percent of men had done so. But 43 percent of women had purchased land while only 36 percent of men had done so (Aslihan Kes, Krista Jacobs and Sophie Namy 2011).
} 
countries are primarily forms of self-employment. A World Bank (2010) study of entrepreneurship in Latin America found that personal savings are the main source of funding to start a business, for both small and larger businesses, whether owned by women or men. ${ }^{6}$ However, women are more likely than men to use their own savings as start-up capital. Among the reasons reported for women's lower use of credit was their inability to provide collateral if major household assets are registered only in the name of the male household head.

In their review of the literature, Leora Klapper and Simon Parker (2010) find that women entrepreneurs have more limited access to capital for their businesses and are less likely to rely on formal financial institutions than men. Some of the studies they analyze from Latin America have found that the main gender difference is on the demand side, rather than outright discrimination, since women are less likely than men to apply for formal financing to maintain or expand their business. On the other hand, they report on studies from a number of developing countries that have documented the many barriers women face in acquiring formal business loans, from low financial literacy to the inability to provide collateral or a guarantor for a loan.

The rapid expansion of microfinance programs over the past several decades, has undoubtedly expanded women's access to credit. The impact of these programs, particularly group lending in Asia and Africa, on poverty reduction and/or women's empowerment, have been amply debated. ${ }^{7}$ Although these outcomes may depend on whether loan recipients use their loans to accumulate assets, relatively few studies have focused on this issue, particularly, from a gender perspective. For example, Carina Van Rooyen, Ruth Stewart and Thea De Wet's (2012) systematic review of impact studies of microfinance programs in Sub-Saharan Africa found only 13 studies of sufficient quality to measure the causal impact of credit or credit plus savings interventions on outcomes. ${ }^{8}$ Of these, only five measured the impact on asset accumulation. While all five of these studies utilized samples that included both men and women, only two included an analysis by gender of the loan recipient, and only one identified which household member owned the asset acquired with the credit.

Neither of the two that included a gender analysis found gender differences in asset accumulation as a result of the microfinance program. Carolyn Barnes, Gary Gaile and Richard Kibombo's (2001) longitudinal study of microcredit programs aimed at microentrepreneurs in Uganda found that program clients significantly increased the amount spent on acquiring business assets compared to non-clients, with no significant difference by gender of the loan recipient.

\footnotetext{
${ }^{6}$ This pattern has also been found in many developed countries. Susan Marlow and Dean Patton (2005) argue that one of the reasons women tend to have smaller businesses than men is that their personal savings are conditioned by their prior labor market experience. Moreover, businesses that are initially undercapitalized also tend to underperform.

${ }^{7}$ Milford Bateman and Ha-Joon Chang (2012) provide a powerful political economy analysis of why microcredit programs are unlikely to lead to sustainable poverty reduction. For a systematic review of impact studies of microcredit on the wellbeing of the poor see Maren Duvendack, Richard Palmer-Jones, James Copestake, Lee Hooper, Yoon Loke and Nitya Rao (2011). They found that many of the studies that claim a positive impact of microcredit are methodologically flawed. See Naila Kabeer (2005) and Linda Mayoux (1999) for a good summary of the issues regarding women's empowerment and microfinance.

${ }^{8}$ The systematic review resulted in 15 studies, but two were of micro-savings interventions. Overall, they find that microfinance programs have a limited impact on wealth outcomes, defined as income, expenditure, savings and assets. Non-wealth outcomes in these same studies are examined in Marcel Korth, Ruth Stewart, Carina Van Rooyen and Thea De Wet (2012).
} 
Moreover, client households were more likely than those of non-clients to become homeowners, and the value of all other household durables was similarly higher for clients, with again no difference by gender of the loan recipient. In a study of rural Zanzibar, Tanzania, Conner Brannen (2010) found that the households of both male and female members of village savings and loan association were more likely to be homeowners than those of the control group (made up of new members). In addition, prior year expenditure on durable assets was significantly greater among member households than the control group, but the impact was smaller in households were the woman was the borrower. This study, however, did not ask to whom the assets acquired belonged. In the other high quality studies on the impact of microcredit on asset acquisition any gendered impact must be deduced from the type of asset acquired or the composition of the membership, clearly insufficient for a rigorous gender analysis.

Among more recent studies on Africa, Namizata Binate Fofana, Gerrit Antonides, Anke Niehof and John A. C. van Ophem (2015) focus on both household asset acquisition and women’s empowerment in rural Cote D'Ivoire. They found that women microfinance borrowers had higher incomes and a higher value of household assets than the control group. However, the positive effect was with respect to durable goods that might be owned and used by all household members - a bed, chair, radio and hoe. They found no effect on what they call "women's assets", such as clothing and jewellery.

The growing recognition that microcredit is not a panacea for either poverty reduction or women's empowerment has led to a greater focus on how individuals may be savings constrained. The constraints include banking regulations and charges regarding savings accounts (Thorsten Beck, Asli Demirguc-Kunt and Maria Soledad Martinez Peria, 2008; Pascaline Dupas and Jonathan Robinson (2013) as well as behavioral explanations (Felipe Kast and Dina Pomeranz, 2014; Nava Ashraf, Dean Karlan and Wesley Yin, 2010). Overall, gender analyses of the relationship between savings and asset accumulation are still pretty sparse in the literature. ${ }^{9}$

This paper contributes to filling the lacunae in the literature about how men and women acquire assets through markets. Although the incidence of purchasing immovable property is relatively low in many countries, growing markets for immovable property provide an opportunity for women to acquire property outside of slowly changing inheritance systems. However, participation in asset markets requires access to savings and/or credit, and surprisingly little is known about their relative roles in asset acquisition, as well as the extent to which this relationship is gendered.

\section{Data and Methodology}

In order to collect individual asset ownership data, the Gender Asset Gap project in 2010 fielded nationally representative household surveys in Ecuador and Ghana, and at the state level in Karnataka, India. The surveys utilized a two-stage sampling technique, which resulted in a sample of 2,892 households in Ecuador, 2,170 in Ghana, and 4,110 in India.

\footnotetext{
${ }^{9}$ Many of these studies shed little light on this relationship. For example, in a field experiment in Nepal where a nofee back account was offered to women, the take-up (84\%) and usage (80\%) rates were quite high (Silvia Prina 2015). The impact of the treatment, however, was only measured at the household level, and had no statistically significant impact on the level of household assets (nor income or expenditures) after one year. In this study, it is not clear if the women actually control the bank account.
} 
The surveys employed two instruments, a household and an individual questionnaire. The first instrument collected data on household demographics, livelihoods, and an inventory of physical assets owned by members of the household, identifying the owner of each asset. The individual questionnaire was administered separately to a maximum of two adult members of the household (usually the man and women considered most knowledgeable) and collected further information on ownership of physical assets as well the data on ownership of financial assets and debt.

Although the questionnaires were based on a similar template, they were adapted to the local context in each country following extensive qualitative research. All inquired about the method of acquisition of each of the major assets but the placement of the questions in the instruments differed. ${ }^{10}$ In addition, for Ecuador and Ghana, the survey includes detailed information on each outstanding loan held by the respondent and identifies the source and purpose of each loan. ${ }^{11}$ We can identify the person or persons responsible for repaying each loan, whether the loan was used to acquire or enhance immovable property or businesses or to purchase livestock, agricultural equipment and consumer durables, and whether it was obtained through formal or informal sources.

Our primary aim in this paper is to establish whether there are broad patterns in how assets are acquired across countries, whether there are any systematic gender differences in the modes of asset acquisition, and whether this depends on the type of asset, specifically, immovable property versus businesses. Once we establish whether there are gender differences in participation in asset markets, we analyze whether there are systematic differences by gender in the use of savings versus credit to finance these purchases and by type of asset.

Our analysis relies upon descriptive statistics to establish patterns. What is relatively unique about our data sets is that we have gender-disaggregated data on each asset that is currently owned and how it was acquired. Our contribution is thus to examine a new question considering multiple assets in a comparative framework.

Data limitations do not allow us to answer the interesting question of what distinguishes women (or men) who were able to purchase assets from those who were not. While we collected information on the year that the various assets were acquired (and can thus deduce the age at which a person acquired the asset), we did not collect information on marital status, education, locale and employment at the time of purchase. Many of these, particularly marital status and locale, may have changed. Since we are dealing with retrospective data, we are hesitant to carry out an analysis even by current rural-urban locale of residence, since all three of our countries, but particularly Ecuador and Ghana, have been characterized by a high degree of internal and

\footnotetext{
${ }^{10}$ In the Ecuador questionnaire, these questions were located in the household inventory. When the household consisted of a principal couple, they answered these questions together whenever possible. In Ghana, questions about the acquisition of the main residence was asked in the inventory, whereas questions about agricultural land, other real estate, and businesses were asked in the individual questionnaire. In Karnataka, these questions were in the individual section and were answered by the person who was considered most knowledgeable about all of the owned assets. The second respondent in the household was asked about the modes of acquisition only of the assets that she or he owned.

${ }^{11}$ Differences in how the questions concerning outstanding loans were asked do not make it possible to distinguish the purpose of many of the loans in Karnataka.
} 
international migration over the past several decades. In such contexts, even ethnicity may be fluid, precluding a rigorous analysis of intersectionality.

An example from our qualitative research may best illustrate our concern of why it might be inappropriate to consider a person's current characteristics adequate predictors of their likelihood to purchase an asset. In urban Ecuador we were surprised by the number of women who had themselves purchased either the housing lot upon which they had subsequently built a dwelling with their partner, or who owned a second urban dwelling. The focus group discussions and interviews indicated that some of these purchases had been facilitated by their inheritance of a land parcel in their community of origin, which they subsequently sold. While in the survey, this second urban dwelling would accurately appear as purchased with the use of savings, her individual characteristics today — urban, mestizo, married, perhaps a housewife — might differ greatly from those at the time of the purchase-rural, indigenous, single, and an unpaid worker on a family farm.

\section{Patterns of Asset Ownership}

Before considering the patterns of asset acquisition, it is useful to have a sense of the gendered patterns of ownership in these three countries. Figure 1 presents the incidence of current asset ownership among adult (18 years and over) men and women for the four key assets. ${ }^{12}$ A person is considered an owner regardless of whether they own the asset individually or jointly. The most commonly owned asset, by either men or women, is the principal residence. The one exception is that in Ghana the asset most often owned by women is a business, although many of these are very small.

In Karnataka, men are also likely to own agricultural land, and there is a large gender gap. In Ghana, much of the agricultural land is not owned by individuals but rather, is held under customary tenure. Considering only land that is private property, there is also a large gender gap. In Ecuador, which is much more urbanized than the other two countries, only seven percent of individuals nationally are landowners, but there is no gender gap in ownership rates. Relatively few people own other real estate in any of the three countries, with the highest incidence being among men in Ghana. Finally, businesses exhibit a different pattern than immovable property. In both Ghana and Ecuador, a larger share of women than men own businesses. The gender gap in favor of men persists in Karnataka.

\section{Asset Acquisition in Ecuador, Ghana, and Karnataka}

Consider first the overall pattern of acquisition by type of asset, depicted in Figure 2. In the case of the main residence, in both Ecuador and Ghana the majority are acquired through the market, either through purchase or by construction of the dwelling. ${ }^{13}$ In contrast, the majority of residences in Karnataka are inherited. The "other" category refers primarily to government programs or community transfers.

\footnotetext{
${ }^{12}$ A more detailed discussion of the patterns of asset ownership in these three countries is provided in Cheryl Doss, Carmen Diana Deere, Abena Oduro, and Hema Swaminathan (2014).

${ }^{13}$ Henceforth, "purchase” is used to refer to both purchases as well as the construction of the dwelling or another building.
} 
In all three countries, the most common way that agricultural land is acquired is through inheritance or gifts. ${ }^{14}$ Ecuador shows the highest incidence of land acquired through the market. In both Ghana and Karnataka, a relatively small share of land parcels is acquired through the market. In Ghana, “other” forms have been important such as claiming ownership of community (lineage) lands.

The acquisition of other real estate in Ecuador and Ghana tends to follow the same pattern as the dwelling, with the most common mode of acquisition being purchase and/or construction. In contrast, in Karnataka, other real estate is more frequently inherited than purchased.

Businesses show a markedly different pattern than immovable property: in all three countries, most businesses are acquired through purchase or started up through self-efforts, with inheritance being of relatively minor importance. This largely reflects the importance of self-employment in developing countries.

In broad strokes, this comparative analysis suggests that the relative importance of inheritance in acquiring immovable property is associated with the degree of rurality and the breadth and depth of asset markets. As countries urbanize, inheritance of land becomes relatively less important and the acquisition of dwellings through the market relatively more important. However, even in Karnataka, which is the most rural of the three sites and where inheritance dominates in the acquisition of property, the market plays at least some role in the acquisition of the residence and other real estate, while less so in terms of agricultural land.

In order to consider the gendered patterns of asset acquisition, we consider the mode of acquisition by the form of ownership, by country (tables 1 to 3). We categorize four types of ownership: owned by a man individually, by a woman individually, jointly by a couple, and “other" joint ownership. The last category includes assets jointly owned by two or more household members other than the main couple, as well as assets owned jointly by a household member with someone residing outside the household. ${ }^{15}$

The dominant form of ownership differs strikingly across the three countries (note the number of assets owned in tables 1 to 3). To a large extent, this reflects differences in the marital property regime. In Ecuador, most agricultural parcels, main residences, and other real estate are owned jointly by a couple, reflecting its partial community property regime. The exception to this pattern is businesses, where individual ownership dominates. In Ghana and India, the separation of property marital regime does not confer joint property rights to individuals upon marriage, thus most property is owned individually, with a gender gap in favor of men for all forms of property except businesses in Ghana.

Most notable, is that the patterns of acquisition vary not only across assets, but also depending on whether the assets are owned by men, women, or jointly. In Ecuador, couples are significantly more likely than individual owners to acquire all forms of immovable property and businesses through the market. In both Ghana and Karnataka, this pattern holds true for dwellings and

\footnotetext{
14 “Inheritance” will be used to refer to property that is transferred as gifts, "en vivo”, as well as upon death.

${ }^{15}$ For some of the questions about asset acquisition, respondents could report multiple modes of acquisition for a single piece of property. This was more common in Karnataka than the other countries, especially for residences.
} 
agricultural land; for other real estate and business, the share of assets acquired through the market is greatest for those owned solely by men.

Comparing just those assets owned individually by a man or a woman, for most types of property a greater percentage of those owned by men are acquired through the market than those owned by women. ${ }^{16}$ These differences are statistically significant in the case of dwellings in Karnataka and Ghana; land in Ecuador; other real estate in Karnataka and Ghana; and businesses in the case of Ecuador and Karnataka. Thus, we find differences in the patterns of mode of acquisition by gender: a smaller share of women's assets is acquired through the market.

Overall, the assets owned by couples are most likely to have been acquired through the market, followed by those owned solely by men and, lastly, those owned solely by women. This smaller incidence of purchase by women could be due to biases against them either in asset markets, and/or in access to the means of financing their purchase. In the next section, we focus on whether men and women differentially use savings and credit to purchase assets.

\section{How Are Assets Acquired Through the Market?}

To purchase immovable property or businesses, people use some combination of savings and credit. Tables 1 to 3 also provide information on the percentage of purchased assets that were acquired using any savings at all, any credit at all, or both to acquire the asset. (Note that these three categories are not exclusive; someone who used both savings and credit would be included in all three columns. ${ }^{17}$ )

All four types of assets are much more likely to have been purchased with savings rather than credit in all three countries. This reflects the limited availability historically of access to credit for purchasing immovable property and for business start-ups. The extent to which any credit has been used varies across the three countries. Use of credit is more common in Karnataka than in Ecuador, except in the case of other real estate. In Ghana, the use of credit for acquiring any of these assets has been relatively infrequent. The asset in Ecuador and Karnataka most likely to have been purchased with any credit is the main residence; in Ghana, it is land or businesses, although credit was used to acquire fewer than 5 percent of these.

It is also more common in Karnataka for many of these assets to have been purchased using both credit and savings than in the other two sites. For example, 36 percent of the purchased dwellings in Karnataka were acquired using both credit and savings, compared to only 19 percent in Ecuador and less than one percent in Ghana. Thus, although it is much more common to acquire immovable property and business through savings than credit in all three countries, there are differences among them in the extent to which credit has been used. Figure 3 summarizes the differences in the use of credit to acquire the main residence, agricultural land, and businesses by the form of property ownership.

\footnotetext{
${ }^{16}$ The significance tests for individually owned assets are not reported in tables 1 to 3 , and are available from the authors.

${ }^{17}$ Not shown is the category of "other" that includes government programs, for example, that provide a grant which is then coupled with either savings or a loan. Other also includes remittances that are sometimes also combined with a person's own savings or a loan.
} 
In Ecuador, the residences and land parcels owned by couples are significantly more likely to have been purchased with the use of credit than those owned by individual owners (a pattern that holds for other real estate, see Table 1). Among assets owned by individual owners, while there is no gender gap in the use of credit to acquire a dwelling, other real estate, or a business, individual female owners are significantly more likely than individual male owners to have acquired their land with the use of credit. However, relatively few women landowners have acquired their parcels through the market.

In Ghana, the use of credit to acquire these four types of assets is so limited that the differences by type of ownership are not significant overall. However, examining the share of individually owned assets acquired via the use of credit suggests that women more frequently than men have acquired their main residence or a business with the use of credit.

In Karnataka, the dwellings owned by couples are equally likely as those owned by men to have been purchased with credit; the only statistically significant difference is that between men and women. In the case of land, the parcels owned by couples are significantly more likely than those owned by individuals to have been purchased with credit, although the gender difference among individually owned assets is not significant. The acquisition of other real estate follows a similar pattern to land. With respect to businesses, the gender differences stand out, with businesses owned by men and couples being more likely to have been started with the use of credit than those owned by women.

In sum, our most important finding is how in the three sites, most immovable assets and businesses that have been acquired through the market have relied upon savings rather than credit, and how this holds for both men and women. Most of the differences in the use of credit - with the exception of Ghana where its use for asset acquisition has been infrequent - are driven by the fact that couples tend to be more likely than individuals to use credit to acquire any of these assets. Notwithstanding, only in Karnataka is there a notable gender gap in the use of individual credit to acquire assets. This raises the question of the extent to which couples are favored over individual borrowers by financial institutions, given that they are more likely to be composed of two income earners, and draws attention to the importance of considering institutional variables.

\section{Credit for Asset Accumulation}

We turn now to the use of credit for the acquisition of assets and address this from a different perspective. Rather than considering how specific assets were acquired, we analyze current outstanding asset loans. For this analysis, we consider loans to acquire a broader group of physical assets: besides borrowing to acquire or enhance immovable property and businesses, ${ }^{18}$ we include loans to purchase livestock, agricultural equipment, and consumer durables. ${ }^{19}$ This analysis is only carried out for Ecuador and Ghana, since differences in how the questions

\footnotetext{
${ }^{18}$ We do not distinguish between borrowing to acquire a home, for example, and loans to expand or improve the dwelling; similarly, in the case of businesses, we do not distinguish between purchasing a business, borrowing to initiate one (start-up costs) and expanding it by investing in physical or working capital.

${ }^{19}$ All of these assets may serve as collateral, particularly for loans from savings and loan cooperatives or the informal sector. Consumer durables may also provide the potential means for income generating activities should the need arise, or be pawned or sold to meet debt repayment.
} 
concerning outstanding loans were asked do not make it possible to distinguish the purpose of many loans for Karnataka. ${ }^{20}$

As Table 4 shows, in Ecuador a much larger share of respondents have outstanding loans to accumulate assets than in Ghana, 28 percent versus 12 percent. This result is consistent with the data provided earlier that showed that very little of the immovable property and businesses in Ghana has been acquired through the use of credit. In Ecuador there is a notable gender gap in men's favor in accessing credit for asset acquisition, while the incidence of men and women accessing asset loans in Ghana is similar.

The asset loans included above may be from formal or informal sources. In Ecuador, formal sector loans are defined as those from a private or public bank, a savings and loan cooperative or credit union, department stores, NGOs or other private institutions, housing developers, and credit card debt. The informal sector includes loans from family, friends, employers, informal credit groups, moneylenders and other. Overall, most asset loans, 81 percent, are from the formal sector (see Table 5). A slightly higher share of loans which are held jointly, either by the couple or by two or more people, are from the formal sector than are those which are held individually by either a man or a woman alone.

In Ghana, formal loans comprise those from banks, non-governmental organizations, credit cooperatives and microfinance institutions. The majority of asset loans are from the informal sector, and only 12 percent are from the formal sector. The heavy reliance on informal sector credit for asset acquisition in Ghana, compared to Ecuador, is consistent with typical indicators of the level of financial development across countries. In 2010 the ratio of private credit to GDP was 27.9 percent in Ecuador and 13.8 percent in Ghana. ${ }^{21}$

Similar to Ecuador, jointly held loans in Ghana are more frequently from the formal sector compared to individually held loans. We would expect this result if formal institutions, such as private banks, prefer lending to couples (or two relatives) if two income earners are considered more likely to repay a loan than a sole borrower. These joint loans might also reflect the fact that two people might better able to come up with the collateral required for a bank loan. In the case of Ecuador, this tendency is also favored by the marital regime. If a person is married, housing mortgages and loans for vehicles are legally required to be signed by both spouses since both are responsible for the debt, and would thus be reported as joint loans. Mortgages and vehicles loans are more readily available in Ecuador than in Ghana, and a larger share of households take out loans for these purposes. ${ }^{22}$

\footnotetext{
${ }^{20}$ See Caren Grown, Carmen Diana Deere, Zachary Catanzarite, Abena D. Oduro, Suchitra J.Y., Hema Swaminathan and Louis Boakye-Yiadom et al. (2015) for a detailed explanation on how information on borrowing activities was gathered in the survey instruments and for an analysis of the differences between borrowing for the purpose of asset accumulation and expenses. In Ecuador, 67 percent, and in Ghana, 58 percent of the total loans reported were for the purpose of asset accumulation (Ibid: Table 8).

${ }^{21}$ Based on the World Bank Financial Structure and Economic Development data base, for private credit by deposit money banks and other financial institutions as a share of GDP. http://econ.worldbank.org/WBSITE/EXTERNAL/EXTDEC/EXTRESEARCH/0,,contentMDK:20696167 pagePK: 64214825 piPK:64214943 theSitePK:469382,00.html. (Accessed July 20, 2015.)

${ }^{22}$ In Ecuador, 8 percent of households have a mortgage on their principal residence, while 2.6 percent have borrowed to acquire other real estate and 2.9 percent, a vehicle. In Ghana, less than one percent of households nationally have been able to borrow for any of these purposes. Less than one percent of households in either country have borrowed to acquire agricultural land (Grown et al., 2015: Table 2).
} 
Whereas in Ecuador the share of individual asset loans that are from formal institutions is similar for men and women, there is a gender gap favoring men in Ghana. These differences are largely explained by the fact that Ecuador has a much more diversified formal sector than Ghana. In Ghana formal lending is concentrated in private banks, whereas in Ecuador installment credit by department stores predominates among formal sector loans, and savings and loan cooperatives are almost as important a source of credit as private banks. Whereas the former institutions are equally important sources to men and women, there is a slight male bias in Ecuador among private as well as state banks as a source of formal loans. ${ }^{23}$

Both countries have experienced the rapid growth of microfinance institutions in recent years. ${ }^{24}$ In Ghana, nonetheless, our survey revealed that loans from microfinance institutions and other private/NGO loan program still represent a very small share of total loans. In Ecuador, the microfinance sector includes seven of the 24 private banks, all of the savings and loans cooperatives, and other private/NGO loan programs. Unfortunately, the microfinance activities of private banks cannot be distinguished in our survey; other private/NGO loans also constitute a very small share of total loans (Grown et al. 2015: Table 9).

Our analysis of the credit requirements of private banks in both countries suggest that these tend to favor clients who have stable wage employment and/or a savings or checking account at their institutions. ${ }^{25}$ In both countries, it is more common for wage workers to have a bank account, since there is a growing tendency for paychecks to be deposited directly in an account, virtually making holding a bank account a requirement of the job. In Ecuador, 54.5 percent of male respondents, but only 23.5 percent of female respondents reported themselves as wage workers; the corresponding figures for Ghana were 20.2 percent and 5.7 percent. Hence, gender differences in the rate of formal wage employment are likely to be reflected in gender differences in the incidence of having a bank account and access to formal credit. Indeed, women in Ghana are much less likely than women in Ecuador to own formal accounts, and the gender gap in favor of men in the ownership of formal accounts is wider in Ghana (Cheryl Doss, Carmen Diana Deere, Abena D. Oduro and Hema Swaminatham 2012).

Other requirements to opening a bank account include having a national identification card (and in Ecuador, proof of having voted); proof of residence (such as a utility bill), and often, having a guarantor. These may also create gender differentiated constraints, if women are less likely to have an identification card, have utility services in their own names (or access at all, in the case of Ghana), or if their social networks are less conducive to producing viable guarantors for formal loans than men's.

An econometric analysis of access to asset loans for Ecuador - where these are predominantly from the formal sector-found that the likelihood of having an asset loan for both men and women was positively associated with having a formal bank account (Deere and Catanzarite 2017). Earning an income increased the likelihood of having an asset loan for women, but not for men, while being a member of a social network increased it only for men. This latter result is likely related to the different kinds of groups to which men and women belong in Ecuador, primarily trade unions and sporting associations among men, and religious groups and parents'

\footnotetext{
${ }^{23}$ See Grown et al. (2015: Table 9), for the distribution of all formal and informal loans by specific sources.

${ }^{24}$ On Ghana, see Joseph Kimos Adjei, Thankom Arun and Farhad Hossain (2009); on Ecuador, see Carmen Diana Deere and Zachary Catanzarite (2017).

25 This analysis is based on the study of the web pages of the main private banks as well as interviews.
} 
associations among women, with perhaps men's groups more likely to include members who might be good guarantors of a loan. While earning an income does not differentiate among men who are able to borrow to acquire assets, belonging to a union reflects the importance of the form of employment, in this case, formal sector employment. ${ }^{26}$

\section{Conclusions}

In analyzing the retrospective patterns of the acquisition of immovable property and businesses in Ecuador, Ghana, and Karnataka, India, we find that these differ by gender in ways that could have important implications for policies to strengthen women's property rights. Our analysis shows that in all three countries women have acquired fewer assets through the market than men. While inheritance is still the dominant means of transferring immovable property, particularly agricultural land, asset markets are increasingly important in Ecuador and Karnataka, while less so in Ghana. This is especially true for the acquisition of dwellings in the former two countries and business start-ups in all three. It is thus useful to consider ways other than inheritance to increase women's property ownership because social norms and inheritance practices are slow to change even when there is the political will to bring about legal change. The broad policy question is the extent to which the market may facilitate their accumulation of assets.

Our second major finding pertains to the primacy of savings in facilitating asset purchase. In all three countries, the main way that men and women were able to buy immovable assets and businesses was using their own savings. Credit was also used but to a more limited extent, and showed a much higher incidence in Ecuador and India than in Ghana. There were substantial gender gaps in the use of credit for asset acquisition, most notably in India, which points to the need for credit markets to widen both reach and target populations and expand in an inclusive manner..

Our analysis also indicates that, couples were more likely than individual owners to have relied upon credit to purchase assets. In Ecuador, given the community of property marital regime, one might expect a relatively high incidence of joint ownership of property by couples, and that they seek loans jointly to acquire assets. In contrast, in a country like India, with separation of property, that couples are more likely than individuals to seek credit for the acquisition of assets, could point to a positive change in gender relations, since it implies that women are being included by their spouses in the process of purchase.

Our analysis of current borrowing for asset acquisition in Ecuador and Ghana, however, suggests considerable efforts will be required to fully incorporate women to credit markets. While financial deepening and greater credit availability is associated with the process of economic development, there is no guarantee that this process will be gender neutral, particularly with respect to access to private bank credit, which is usually cheaper than credit from other sources. An important insight from Ecuador's experience is that the expansion of savings and loan cooperatives, as well as installment credit can play a key role in enhancing women's access to

\footnotetext{
${ }^{26}$ There was no significant difference in the likelihood of an asset loan by locale of residence, Both Afro-Ecuadorian men and women were significantly more likely to have asset loans than white/mestizos. Our subsequent qualitative research suggests that this finding probably reflects the rapid expansion of department store installment credit rather than microfinance institutions in the region where the majority of Afro-Ecuadorians in the sample are located.
} 
credit for the accumulation of assets. Also important is women's ownership of a bank account which could enable them to accumulate savings and access formal credit.

Other types of microfinance institutions, besides cooperatives, can potentially play an important role in expanding women's access to formal credit for the acquisition of assets, but have been of relatively limited reach thus far in the overall picture in both Ecuador and Ghana. ${ }^{27}$ Our review of the literature on microfinance programs highlighted how in the evaluation of these programs, insufficient attention has been given to the role of microcredit in facilitating asset acquisition in general, and specifically, whether loans taken out by women result in their ownership of assets, either individually or jointly with their partners. The absence of data on which household member acquired assets with credit is a serious shortcoming, since it stymies the analysis of whether women borrowers themselves benefit from such programs by strengthening their fallback position in household negotiations, or whether they are merely the conduit for asset accumulation by other household members, especially their partners.

A precondition for women borrowers to be able to utilize their loans for asset accumulation is that they need to be able to control how their loans are utilized, as stressed by Garikipati (2008) and others. In the case of microentrepreneurs, the business environment must also be sufficiently favorable to justify an investment in greater fixed capital and stock, a condition not always met in the sectors in which women microentrepreneurs tend to be located (Klapper and Parker 2010). Finally, women need access to loans that are large enough to purchase assets, particularly larger assets. The evidence is mixed thus far as to whether there is a glass ceiling on loan size (Corsi and de Angelis, 2017; Agier and Szafarz, 2013).

Our analysis is limited by the data available. While our surveys provide the most detailed data available on individual asset ownership, they were not designed to provide a full history of the accumulation of immovable property and businesses. For a more complete analysis, a comprehensive profile of all immoveable property and businesses acquired by individuals over a given time horizon would be imperative, including information on their location, marital status, employment status and other individual and household attributes at the time of purchase. Our findings point to the importance of such data collection efforts in the future given that markets are increasingly becoming critical means of asset accumulation.

Our findings regarding the importance of savings in the acquisition of assets support the growing emphasis in development policy and in the literature on how efforts to promote financial inclusion should focus not just on expanding access to credit but also to savings accounts. As Beck et al. (2008), Kast and Pomeranz (2014) and others argue, greater attention must be given to the constraints that individuals face in opening a bank account. These constraints are monetary, in terms of the costs of opening and maintaining an account; institutional, in terms of the requirements (such as multiple documents) to open an account; as well as cultural, in terms of whether it is considered appropriate for women to participate in financial markets.

Finally, our analysis also points to the importance for women of having steady incomegenerating employment in order to be able to participate in asset markets. Employment and the level of income thereby generated directly influences the ability to save as well as access to credit geared to asset accumulation.

\footnotetext{
${ }^{27}$ In the case of Ecuador, the data does not allow us to analyze the specific role of microfinance banks within private bank credit. Loans from NGO microfinance programs constitute less than four percent of the total loans.
} 


\section{References}

Adjei, Joseph Kimos, Thankom Arun, and Farhad Hossain. 2009. The Role of Microfinance in Asset-Building and Poverty Reduction: The Case of Sinapi Aba Trust of Ghana. BWPI Working Paper 87. Manchester, UK: Brooks World Poverty Institute, University of Manchester. www.manchester.ac.uk/bwpi (accessed October 5, 2015) .

Agarwal, Bina. 1994. A Field of One's Own. Gender and Land Rights in South Asia. Cambridge: Cambridge University Press.

Agier, Isabelle and Ariane Szafarz. (2013). Microfinance and Gender: Is there a glass ceiling on loan size? World Development, 42, pp. 165-181.

Ali, Daniel Ayelew, Klaus Deininger and Markus Goldstein. 2014. "Environmental and gender impacts of land tenure regularization in Africa: Pilot evidence from Rwanda.” Journal of Development Economics, 110: 262-75.

Ashraf, Nava, Karlan, Dean, and Wesley Yin. 2010. "Female Empowerment: Further Evidence from a Commitment Savings Product in the Philippines.” World Development 38: 33344.

Barnes, Carolyn, Erica Keogh and Nontokozo Nemarundwe. 2001. Microfinance Program Clients and Impact: An assessment of Zambuko Trust, Zimbabwe. Executive Summary. Washington D.C.: AIMS (Assessing the Impact of Microenterprise Services), October.

Bateman, Milford and Ha-Joon Chang. 2012. "Microfinance and the Illusion of Development: From Hubris to Nemesis in Thirty Years.” World Economic Review 1: 13-36.

Beck, Thorsten., Asli Demirgüç-Kunt, and Maria Soledad Martinez Peria. 2008. "Banking Services for Everyone? Barriers to Bank Access and Use around the World.” World Bank Economic Review 22(3): 397-430.

Binate Fofana, Namizata, Gerrit Antonides, Anke Niehof and John A. C. van Ophem. 2015. "How Microfinance Empowers Women in Cote d'Ivoire." Review of Economics of the Household 13: 1023-41.

Brannen, Conner. 2010. “An Impact study of the Village Savings and Loan Association (VSLA) program in Zanzibar, Tanzania.” Honor’s Thesis, Wesleyan University.

Cooper, Elizabeth and Kate Bird. 2012. "Inheritance: A Gendered and Intergenerational Dimension of Poverty.” Development Policy Review 30(5): 527-541.

Corsi, Marcella and Marina De Angelis. (2017). Gender discrimination in Microfinance? Some evidence from Uganda. The Journal of Development Studies, 53 (5), pp.723-740.

Datta, Namita. 2006. “Joint Titling - A Win-Win Policy? Gender and Property Rights in Urban Informal Settlements in Chandigarh, India.” Feminist Economics 12(1-2): 271-98.

Davies, James B. and Anthony F. Shorrocks. 2000. “The Distribution of Wealth.” In Anthony B. Atkinson and François Bourguignon, eds., Handbook of Income Distribution, Vol. 1. (Amsterdam: Elsevier), pp. 605-75. 
Deere, Carmen Diana. 1990. Household and Class Relations. Peasants and Landlords in Northern Peru. Berkeley: University of California Press.

Deere, Carmen Diana and Zachary B. Catanzarite. 2017. "Who Borrows to Accumulate Assets? Class, Gender and Indebtedness in Ecuador's Credit Market.” CEPAL Review \#122: 107126.

Deere, Carmen Diana and Cheryl R. Doss. 2006. “The Gender Asset Gap: What Do We Know and Why Does It Matter?” Feminist Economics, 12(1-2), 1-50.

Deere, Carmen Diana and Magdalena León. 2001. Empowering Women. Land and Property Rights in Latin America. Pittsburgh: Pittsburgh University Press.

Deere, Carmen Diana, Abena D. Oduro, Hema Swaminathan, and Cheryl Doss. 2013. "Property Rights and the Gender Distribution of Wealth in Ecuador, Ghana and India.” Journal of Economic Inequality 11(2): 249-65.

Doss, Cheryl, William Baah-Boatang, Louis Boakye-Yiadom, Zachary Catanzarite, Carmen Diana Deere, Rahul Lahoti, Hema Swaminathan, and Suchitra J.Y. 2013. "Measuring Personal Wealth in Developing Countries: Interviewing Men and Women about Asset Values.” Gender Asset Gap Project Working Paper \#15, November. www.genderassetgap.org (accessed February 12, 2017).

Doss, Cheryl, Carmen Diana Deere, Abena D. Oduro, Hema Swaminathan 2012. "Women who save. A Comparative analysis of Ecuador, Ghana and Karnataka India.” Report prepared for United Nations Foundation. www.genderassetgap.org (accessed February 12, 2017).

Doss, Cheryl R., Carmen Diana Deere, Abena D. Oduro, and Hema Swaminathan. 2014. “The Gender Asset and Wealth Gaps.” Development 57(3-4), 400-9.

Doss, Cheryl., Mai Truong, Goretti Nabanoga, and Justine Namaalwa. 2012. "Women, Marriage and Asset Inheritance in Uganda.” Development Policy Review 30(5): 597-616.

Dupas, Pascaline and Jonathan Robinson. 2013. "Saving constraints and microenterprise development: evidence from a field experiment in Kenya.” American Economic Journal: Applied Economics, 5(1), 163-192.

Duvendack, Maren, Richard Palmer-Jones, James Copestake, Lee Hooper, Yoon Loke and Nitya Rao. 2011. What is the Evidence of the Impact of Microfinance on the Well-being of Poor People? EPPI-Centre Report 1912. London: EPPI-Centre, University of London.

Elson, Diane. 1999. “Labor Markets as Gendered Institutions: Equality, Efficiency and Empowerment Issues.” World Development 27(3): 611-27.

Fenrich, Jeanmarie and Tracy E. Higgins. 2001. "Promise Unfulfilled: Law, Culture and Women's Inheritance Rights in Ghana.” Fordham International Law Journal, 25: 259341.

Friedemann-Sánchez, Greta. 2006. “Assets in Intrahousehold Bargaining Among Women Workers in Colombia’s Cut-Flower Industry.” Feminist Economics 12(1-2), 247-69. doi:10.1080/13545700500508551

Garikipati, Supriya. 2008. "The Impact of Lending to Women on Household Vulnerability and Women's Empowerment: Evidence from India.” World Development 36 (12): 2620-42. 
Grown, Caren, Carmen Diana Deere, Zachary Catanzarite, Abena D. Oduro, Suchitra JY, Hema Swaminathan, and Louis Boakye-Yiadom. 2015. Who Borrows? An Analysis of Gender, Debt, and Assets in Ecuador, Ghana, and Karnataka, India. Discussion Paper. New York: UN Women. http://www.unwomen.org/en/digital-library/publications/2015/6/whoborrows-an-analysis-of-gender-debt-and-assets (accessed February 12, 2017).

Kabeer, Naila. 2005. “Is Microfinance a ‘Magic Bullet’ for Women’s Empowerment? Analysis of Findings from South Asia.” Economic and Political Weekly 40 (44/45): 4709-18.

Kast, Felipe and Dina Pomeranz. 2014.Saving More to Borrow Less: Experimental Evidence from Access to Formal Savings Accounts in Chile. National Bureau of Economic Research Working Paper 20239. Cambridge: NBER, June.

Kes, Aslihan, Krista Jacobs and Sophie Namy. 2011. Gender Differences in Asset Rights in Central Uganda. Washington, DC: International Center for Research on Women.

Klapper, Leora F. and Simon C. Parker. 2010. “Gender and the Business Environment for New Firm Creation.” World Bank Research Observer 26: 237-57.

Korth, Marcel, Ruth Stewwart, Carina Van Rooyen and Thea De Wet. 2012. "Microfinance: Development Intervention or Just Another Bank?” Journal of Agrarian Change 12 (4): 575-86.

Lakwo, Alfred. 2006. Microfinance, rural livelihoods, and women's empowerment in Uganda. African Studies Centre Research Report No. 85. Nijmegen: Radboud Universiteit.

Lastarria-Cornhiel, Susana. 1997. "Impact of Privatization on Gender and Property Rights in Africa.” World Development 25(8): 1317-34.

Lastarria-Cornhiel, Susana, Julia A. Behrman, Ruth Meinzen-Dick, and Agnes R. Quisumbing. 2014. "Gender Equity and Land: Toward Secure and Effective Access for Rural Women,” in Agnes R. Quisumbing, Ruth Meinzen-Dick, Terri L. Raney, Andr Croppenstedt, Julie A. Behrman, and Amber Peterman eds., Gender in Agriculture: Closing the Knowledge Gap, 117-44. New York: Springer.

Marlow, Susan and Dean Patton. 2005. “All Credit to Men? Entrepreneurship, Finance and Gender.” Entrepreneurship: Theory and Practice 29 (6): 717-35.

Mayoux, Linda. 1999. “Questioning Virtuous Spirals. Microfinance and Women’s Empowerment in Africa.” Journal of International Development 11: 957-84.

Prina, Silvia. 2015. "Banking the Poor via Savings Accounts. Evidence from a Field Experiment.” Journal of Development Economics 115:16-31.

Salia, Paul J. 2014. "The Effect of Microcredit on the Household Welfare (Empirical Evidences from Women Micro-entrepreneurs in Tanzania).” International Journal of Academic Research in Business and Social Sciences 4 (5): 259-272.

Semyonov, Moshe and Noah Lewin-Epstein. 2013. "Ways to Richness: Determination of Household Wealth in 16 Countries.” European Sociological Review 29 (6): 1134-48.

Sircar, Ashok K. and Sohini Pal. 2014. "What is preventing women from inheriting land? A study of the implementation of the Hindu Succession (Amendment) Act 2005 in three states in India”. Paper presented at the 2014 World Bank Conference on Land and Poverty, Washington, D.C., March $24-27$. 
Van Rooyen, Carina, Ruth Stewart, and Thea De Wet. 2012. “The Impact of Microfinance in Sub-Saharan Africa: A Systematic Review of the Evidence.” World Development 40(11): 2249-62.

UN Women. 2015. Progress of the World's Women 2015-2016. Transforming Economies, Realizing Rights. New York: UN Women

World Bank. 2010. Women's Economic Opportunities in the Formal Private Sector in Latin America and the Caribbean. Washington, D.C.: The World Bank, the Inter-American Development Bank and GTZ. 
Table 1. Incidence of modes of acquisition, by form of ownership, Ecuador

\begin{tabular}{|c|c|c|c|c|c|c|c|c|}
\hline \multirow{2}{*}{$\begin{array}{c}\text { Form of } \\
\text { Ownershi } \\
\text { p }\end{array}$} & \multirow{2}{*}{$\begin{array}{l}\text { Owne } \\
\text { d } \\
\text { Assets } \\
\text { (n) }\end{array}$} & \multirow{2}{*}{$\begin{array}{c}\% \\
\text { Purchas } \\
\text { e/ } \\
\text { construc } \\
\text { t }\end{array}$} & \multirow{2}{*}{$\begin{array}{c}\% \\
\text { Inherite } \\
\mathrm{d}\end{array}$} & \multirow{2}{*}{$\begin{array}{c}\% \\
\text { Other }\end{array}$} & \multirow{2}{*}{$\begin{array}{c}\text { Purchase } \\
\text { d (n) }\end{array}$} & \multicolumn{3}{|c|}{$\%$ of purchasers using: } \\
\hline & & & & & & $\begin{array}{c}\text { Any } \\
\text { saving }\end{array}$ & $\begin{array}{l}\text { Any } \\
\text { credit }\end{array}$ & $\begin{array}{c}\text { Saving } \\
\text { and } \\
\text { credit }\end{array}$ \\
\hline \multicolumn{9}{|l|}{ Main Residence } \\
\hline Man & 253 & 84.6 & 13.0 & 2.4 & 214 & 85 & 32.7 & 18.2 \\
\hline Woman & 429 & 84.2 & 14.9 & 0.9 & 361 & 84.2 & 29.6 & 16.6 \\
\hline Couple & 729 & 93.7 & 4.4 & 1.9 & 683 & 80.2 & 39.1 & 21.2 \\
\hline Other & 316 & 85.4 & 13.9 & 0.6 & 270 & 85.9 & 30 & 17.4 \\
\hline Total & 1727 & 88.5 & 10.0 & 1.5 & 1528 & 82.9 & 34.4 & 19 \\
\hline $\mathrm{p}$ & & 0.000 & 0.000 & 0.192 & & 0.099 & 0.055 & 0.256 \\
\hline \multicolumn{9}{|c|}{ Agricultural Land } \\
\hline Man & 137 & 37.2 & 58.4 & 4.4 & 51 & 94.1 & 5.9 & 0 \\
\hline Woman & 125 & 26.4 & 72.8 & 0.8 & 33 & 93.9 & 18.2 & 12.1 \\
\hline Couple & 174 & 52.9 & 44.3 & 2.9 & 92 & 78.3 & 28.3 & 6.5 \\
\hline Other & 78 & 52.6 & 46.2 & 1.3 & 41 & 80.5 & 7.3 & 0 \\
\hline Total & 514 & 42.2 & 55.3 & 2.5 & 217 & 84.8 & 17.5 & 4.6 \\
\hline $\mathrm{p}$ & & 0.000 & 0.000 & 0.262 & & 0.027 & 0.002 & 0.024 \\
\hline \multicolumn{9}{|c|}{ Other Real Estate } \\
\hline Man & 91 & 58.2 & 38.5 & 3.3 & 53 & 94.3 & 20.8 & 15.1 \\
\hline Woman & 122 & 51.6 & 45.9 & 2.5 & 63 & 79.4 & 33.3 & 17.5 \\
\hline Couple & 121 & 86.8 & 13.2 & 0.0 & 105 & 73.3 & 40 & 13.3 \\
\hline Other & 74 & 51.4 & 48.7 & 1.4 & 38 & 89.5 & 28.9 & 21.1 \\
\hline Total & 408 & 63.5 & 35.1 & 1.7 & 259 & 81.5 & 32.8 & 15.8 \\
\hline $\mathrm{p}$ & & 0.000 & 0.000 & 0.270 & & 0.003 & 0.101 & 0.702 \\
\hline \multicolumn{9}{|l|}{ Business } \\
\hline Man & 505 & 90.1 & 2.0 & 8.7 & 455 & 83.1 & 24.2 & 7.7 \\
\hline Woman & 766 & 85.1 & 3.5 & 12.4 & 652 & 85 & 20.2 & 5.4 \\
\hline Couple & 220 & 97.3 & 0.9 & 1.8 & 214 & 72.9 & 37.9 & 11.7 \\
\hline Other & 258 & 86.1 & 4.7 & 9.7 & 222 & 84.7 & 22.1 & 7.2 \\
\hline Total & 1749 & 88.2 & 0.7 & 9.6 & 1543 & 82.7 & 24.1 & 7.2 \\
\hline $\mathrm{P}$ & & 0.000 & 0.037 & 0.000 & & 0.000 & 0.000 & 0.002 \\
\hline
\end{tabular}

Notes: Respondents could indicate more than one form of acquisition. Significance tests refer to Pearson Chi-sq test across all forms of ownership. 
Table 2. Incidence of modes of acquisition, by form of ownership, Ghana

\begin{tabular}{|c|c|c|c|c|c|c|c|c|}
\hline \multirow{2}{*}{$\begin{array}{c}\text { Form of } \\
\text { Ownershi } \\
\text { p }\end{array}$} & \multirow{2}{*}{$\begin{array}{l}\text { Owne } \\
\text { d } \\
\text { Assets } \\
\text { (n) }\end{array}$} & \multirow{2}{*}{$\begin{array}{c}\% \\
\text { Purchas } \\
\text { e/ } \\
\text { construc } \\
\text { t }\end{array}$} & \multirow{2}{*}{$\begin{array}{c}\% \\
\text { Inherite } \\
\mathrm{d}\end{array}$} & \multirow{2}{*}{$\begin{array}{c}\% \\
\text { Other }\end{array}$} & \multirow{2}{*}{$\begin{array}{c}\text { Purchase } \\
\text { d (n) }\end{array}$} & \multicolumn{3}{|c|}{ \% of purchasers using: } \\
\hline & & & & & & $\begin{array}{c}\text { Any } \\
\text { saving }\end{array}$ & $\begin{array}{c}\text { Any } \\
\text { credit }\end{array}$ & $\begin{array}{c}\text { Saving } \\
\text { and } \\
\text { credit }\end{array}$ \\
\hline \multicolumn{9}{|l|}{ Main Residence } \\
\hline Man & 491 & 84.3 & 15.5 & 0.2 & 414 & 93.5 & 2.2 & 0.7 \\
\hline Woman & 173 & 60.2 & 39.3 & 0.6 & 104 & 80.8 & 2.8 & 1 \\
\hline Couple & 41 & 97.6 & 2.4 & 0.0 & 40 & 92.5 & 2.5 & 2.5 \\
\hline Other & 64 & 14.3 & 85.7 & 0.0 & 10 & 70 & 0 & 0 \\
\hline Total & 769 & 73.8 & 25.9 & 0.3 & 568 & 90.7 & 2.3 & 0.9 \\
\hline $\mathrm{p}$ & & 0.000 & 0.000 & & & 0.000 & 0.934 & 0.702 \\
\hline \multicolumn{9}{|c|}{ Agricultural Land } \\
\hline Man & 937 & 6.7 & 53.3 & 40.0 & 65 & 89.2 & 6.2 & 0 \\
\hline Woman & 299 & 7.0 & 76.3 & 16.7 & 23 & 78.3 & 4.4 & 0 \\
\hline Couple & 38 & 18.4 & 60.5 & 21.1 & 8 & 100 & 0 & 0 \\
\hline Other & 93 & 3.2 & 71.0 & 25.8 & 3 & 66.7 & 0 & 0 \\
\hline Total & 1367 & 6.9 & 59.7 & 33.4 & 99 & 86.9 & 5.1 & 0 \\
\hline $\mathrm{p}$ & & 0.020 & 0.000 & 0.000 & & 0.251 & 0.856 & NA \\
\hline \multicolumn{9}{|c|}{ Other Real Estate } \\
\hline Man & 451 & 78.1 & 18.9 & 3.1 & 353 & 0.22 & 1.55 & 0 \\
\hline Woman & 237 & 59.1 & 37.6 & 3.4 & 140 & 0.42 & 2.11 & 0 \\
\hline Couple & 25 & 76.0 & 24.0 & 0.0 & 19 & 0 & 4 & 0 \\
\hline Other & 9 & 33.3 & 66.7 & 0.0 & 3 & 0 & 0 & 0 \\
\hline Total & 722 & 71.2 & 25.8 & 3.1 & 515 & 0.28 & 1.8 & 0 \\
\hline $\mathrm{p}$ & & 0.00 & 0.00 & 0.76 & & 0.96 & 0.77 & NA \\
\hline \multicolumn{9}{|l|}{ Business } \\
\hline Man & 307 & 94.1 & 5.5 & 0.0 & 289 & 94.8 & 3.1 & 1.0 \\
\hline Woman & 813 & 93.7 & 5.3 & 0.5 & 760 & 87.6 & 5.1 & 0.3 \\
\hline Couple & 22 & 90.9 & 13.6 & 0.0 & 19 & 89.5 & 0 & 0 \\
\hline Other & 20 & 75.0 & 25.0 & 0.0 & 16 & 87.5 & 6.3 & 0 \\
\hline Total & 1162 & 93.5 & 5.9 & 0.3 & 1084 & 89.6 & 4.5 & 0.5 \\
\hline $\mathrm{p}$ & & 0.008 & 0.001 & 0.632 & & 0.009 & 0.393 & 0.406 \\
\hline
\end{tabular}

Notes: Respondents could indicate more than one form of acquisition. Significance tests refer to Pearson Chi-sq test across all forms of ownership. For agricultural land, other ownership claims to family land, clearing prime forest, encroachment, through sharecropping (some types of tenancies allow for eventual ownership) and adjudication by the community or the state. 
Table 3. Incidence of modes of acquisition, by form of ownership, Karnataka, India

\begin{tabular}{|c|c|c|c|c|c|c|c|c|}
\hline \multirow{2}{*}{$\begin{array}{c}\text { Form of } \\
\text { Ownershi } \\
\text { p }\end{array}$} & \multirow{2}{*}{$\begin{array}{l}\text { Owne } \\
\text { d } \\
\text { Assets } \\
\text { (n) }\end{array}$} & \multirow{2}{*}{$\begin{array}{c}\% \\
\text { Purchas } \\
\text { e/ } \\
\text { construc } \\
\text { t }\end{array}$} & \multirow{2}{*}{$\begin{array}{c}\% \\
\text { Inherite } \\
\mathrm{d}\end{array}$} & \multirow{2}{*}{$\begin{array}{c}\% \\
\text { Other }\end{array}$} & \multirow{2}{*}{$\begin{array}{c}\text { Purchase } \\
\text { d (n) }\end{array}$} & \multicolumn{3}{|c|}{ \% of purchasers using: } \\
\hline & & & & & & $\begin{array}{c}\text { Any } \\
\text { saving }\end{array}$ & $\begin{array}{c}\text { Any } \\
\text { credit }\end{array}$ & $\begin{array}{c}\text { Saving } \\
\text { and } \\
\text { credit }\end{array}$ \\
\hline \multicolumn{9}{|l|}{ Main Residence } \\
\hline Man & 2013 & 36.8 & 56.7 & 9.4 & 741 & 82.1 & 54.3 & 38.9 \\
\hline Woman & 738 & 30.5 & 59.4 & 13.7 & 225 & 79.6 & 45.3 & 28 \\
\hline Couple & 130 & 45.4 & 43.1 & 17.7 & 59 & 86.4 & 54.2 & 42.4 \\
\hline Other & 298 & 33.6 & 63.4 & 5.7 & 100 & 79 & 49 & 34 \\
\hline Total & 3,179 & 35.4 & 57.4 & 10.4 & 1125 & 81.51 & 52 & 36.4 \\
\hline $\mathrm{P}$ & & 0.001 & 0.001 & 0.000 & & 0.555 & 0.112 & 0.019 \\
\hline \multicolumn{9}{|c|}{ Agricultural Land } \\
\hline Man & 1867 & 9.3 & 85.8 & 3.8 & 173 & 85 & 41.6 & 28.9 \\
\hline Woman & 363 & 11.9 & 82.1 & 5.0 & 43 & 81.4 & 30.2 & 14 \\
\hline Couple & 65 & 21.5 & 72.3 & 6.2 & 14 & 42.9 & 71.4 & 14.3 \\
\hline Other & 350 & 8.0 & 84.0 & 6.3 & 28 & 100 & 50 & 50 \\
\hline Total & 2,645 & 9.8 & 84.7 & 4.4 & 258 & 83.7 & 42.3 & 27.9 \\
\hline $\mathrm{P}$ & & 0.003 & 0.009 & 0.149 & & 0.000 & 0.043 & 0.006 \\
\hline \multicolumn{9}{|c|}{ Other Real Estate } \\
\hline Man & 552 & 45.7 & 46.0 & 11.1 & 252 & 83.3 & 27.4 & 10.7 \\
\hline Woman & 143 & 37.1 & 49.7 & 14.7 & 53 & 83 & 34 & 17 \\
\hline Couple & 30 & 40.0 & 53.3 & 10.0 & 12 & 91.7 & 66.7 & 58.3 \\
\hline Other & 79 & 20.3 & 69.6 & 8.9 & 16 & 81.3 & 25 & 6.3 \\
\hline Total & 804 & 41.4 & 49.3 & 11.4 & 333 & 83.5 & 29.7 & 13.2 \\
\hline $\mathrm{P}$ & & 0.000 & 0.001 & 0.542 & & 0.884 & 0.028 & 0.000 \\
\hline \multicolumn{9}{|l|}{ Business } \\
\hline Man & 429 & 87.0 & 13.1 & 0.0 & 373 & 64.9 & 41.3 & 6.2 \\
\hline Woman & 130 & 78.5 & 19.2 & 0.0 & 102 & 73.5 & 26.5 & 2.9 \\
\hline Couple & 69 & 79.7 & 18.8 & 0.0 & 55 & 65.5 & 40 & 5.4 \\
\hline Other & 102 & 70.6 & 29.4 & 0.0 & 72 & 73.6 & 40.3 & 13.9 \\
\hline Total & 730 & 82.5 & 17.0 & 0.0 & 602 & 67.4 & 38.5 & 6.5 \\
\hline $\mathrm{P}$ & & 0.001 & 0.001 & & & 0.101 & 0.055 & 0.032 \\
\hline
\end{tabular}

Notes: Respondents could indicate more than one form of acquisition. Significance tests refer to Pearson Chi-sq test across all forms of ownership. 
Table 4: Incidence of outstanding loans for asset acquisition

\begin{tabular}{llll} 
Country & Women & Men & Total \\
\hline Ecuador & $24.1 \%$ & $32.7 \%$ & $27.8 \%$ \\
$\mathrm{~N}$ & 2656 & 2012 & 4668 \\
Ghana & $12.2 \%$ & $11.8 \%$ & $12.1 \%$ \\
$\mathrm{~N}$ & 1790 & 1481 & 3271 \\
\hline
\end{tabular}

Note: the total refers to those answering the individual questionnaire in our respective surveys.

Table 5: Distribution of asset loans by person(s) responsible for repayment and source of credit (\%)

Formal sector Informal Total loans

sector

\begin{tabular}{rrrr}
\hline $\begin{array}{l}\text { Ecuador } \\
\text { Woman alone }\end{array}$ & 78.9 & 21.1 & $100 \mathrm{n}=384$ \\
Man alone & 78.4 & 21.6 & $100 \mathrm{n}=486$ \\
Couple & 86.2 & 13.8 & $100 \mathrm{n}=318$ \\
Other joint & 89.1 & 10.9 & $100 \mathrm{n}=64$ \\
Total & 81.1 & 18.9 & $100 \mathrm{n}=1252$ \\
Ghana & & & \\
Woman alone & 9.5 & 90.5 & $100 \mathrm{n}=201$ \\
Man alone & 12.7 & 87.3 & $100 \mathrm{n}=150$ \\
Couple & 27.3 & 72.7 & $100 \mathrm{n}=11$ \\
Other joint & 28.6 & 71.4 & $100 \mathrm{n}=\mathbf{7}$ \\
Total & 11.7 & 88.3 & $100 \mathrm{n}=369$ \\
\hline
\end{tabular}

Notes: In Ghana, the source of loan could not be identified for all asset debt. 
Figure 1. Incidence of ownership of key assets by adults, by sex and country.

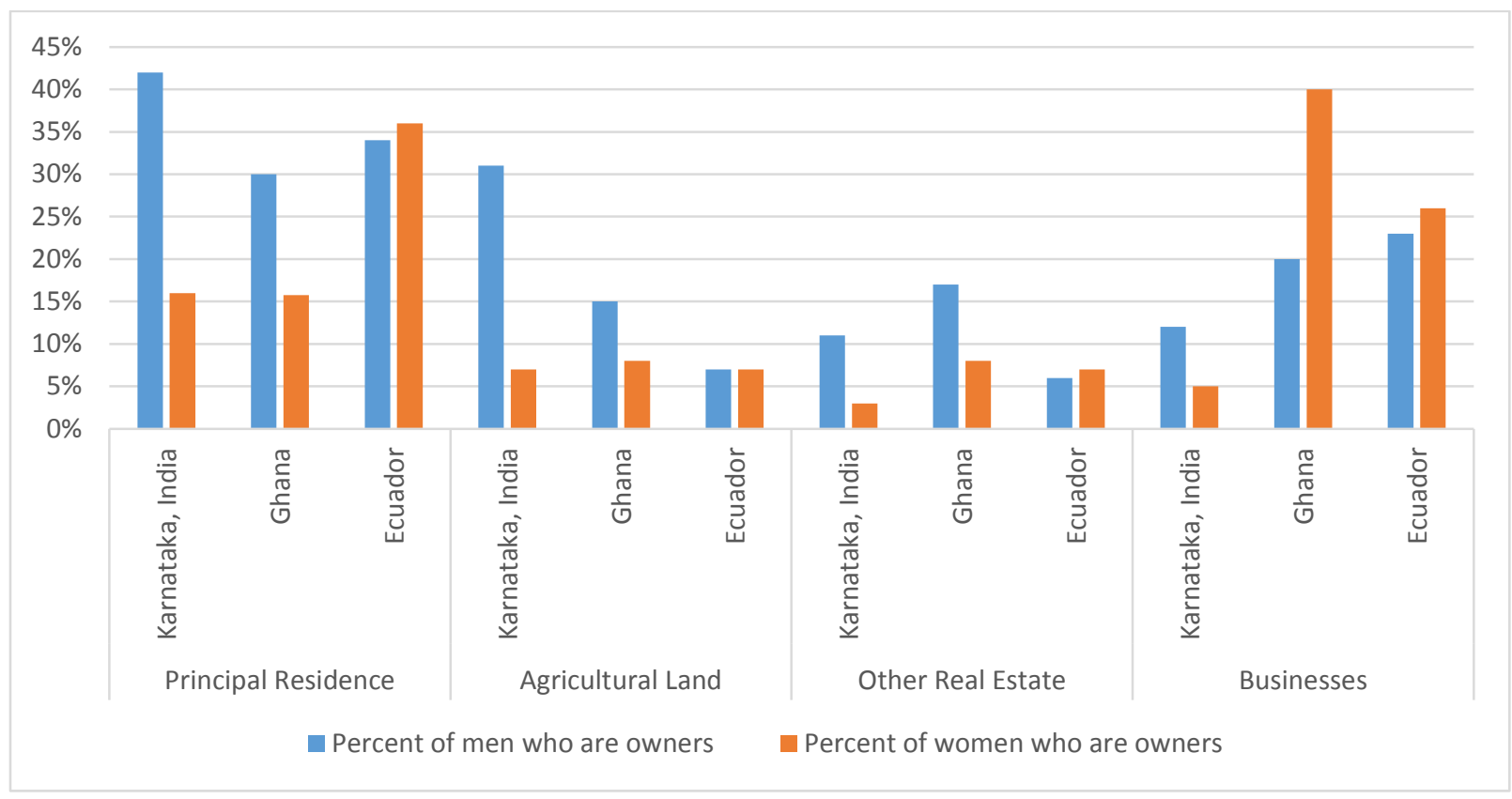

Figure 2: Mode of acquisition of immovable property and businesses (percent of currently owned assets acquired through purchase, inheritance and other means.)

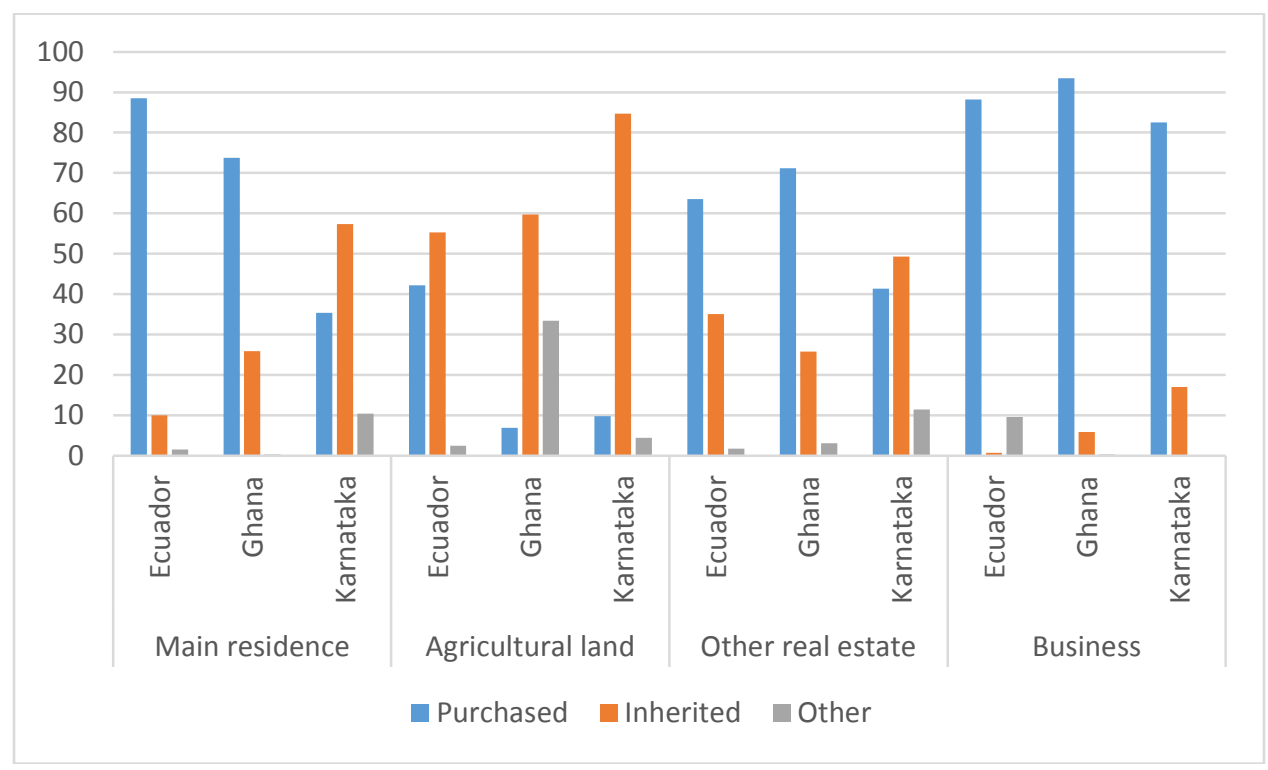


Figure 3: Percentage of residences, agricultural parcels, and businesses which were acquired with credit (partially or totally), by form of ownership.

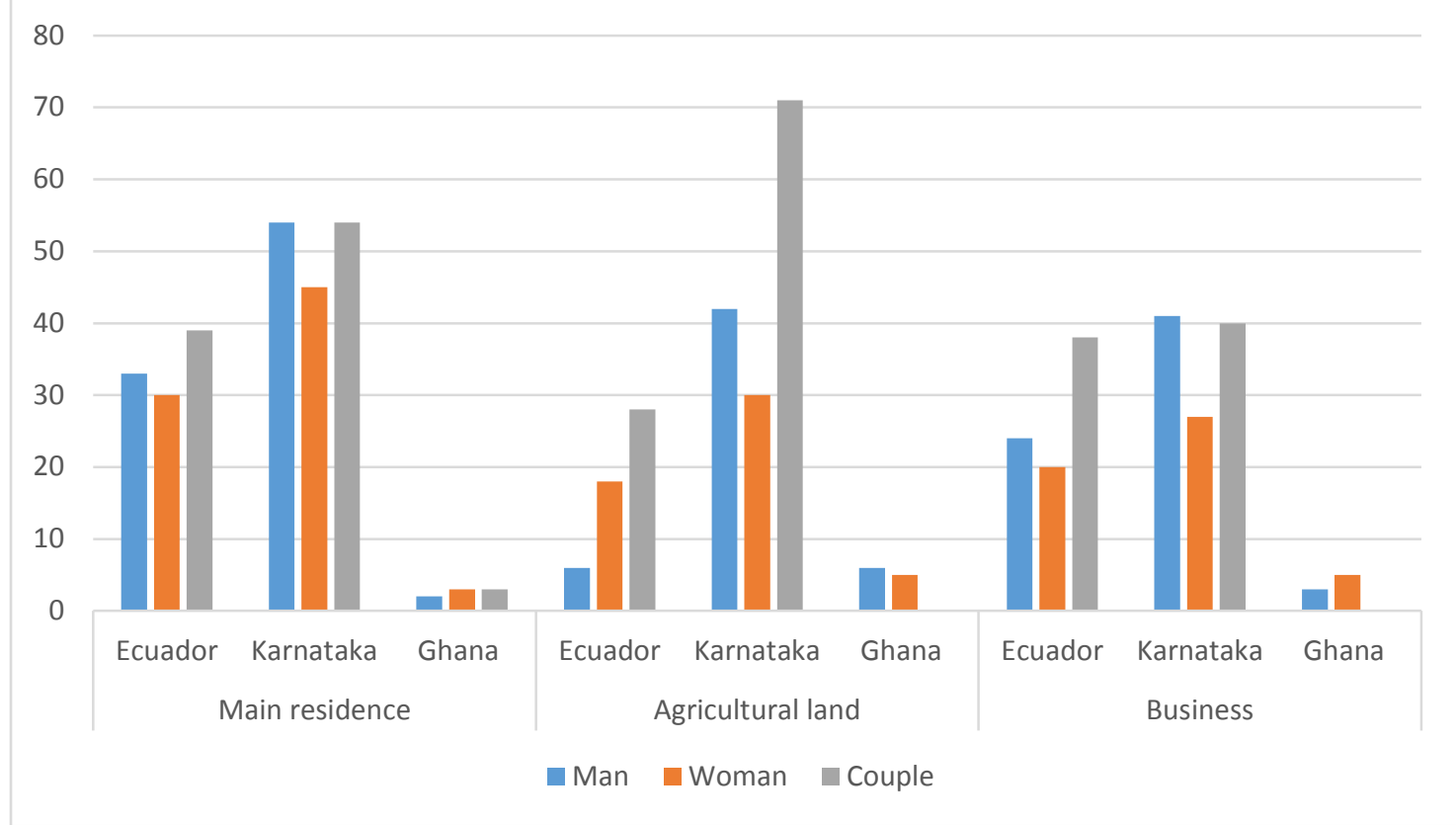

